\title{
FIQH AL-AQALLIYYAH AND MUSLIM MINORITIES IN A NON-MUSLIM COMMUNITY
}

\author{
Kazeem Adekunle Adegoke ${ }^{1}$
}

\begin{abstract}
This study researches into the legal theory offiqh al-aqaliyyah and Muslim minorities in a contemporary non-Muslim community. In order to achieve this objective, the paper examines the fiqh alaqalliyyah, its legal position in Islamic jurisprudence, its legal instruments and its applicability to lessen the physical, social, financial and emotional hardships or difficulties encountered by Muslim minorities who find themselves in an unfamiliar nonMuslim environment. Research method used in this study is expository, descriptive and analytical in order to showcase the applicability of fiqh al-aqalliyyah in the modern legal theory within the context-specific and needs-based neo-ijtihād legal rulings for Muslim minorities. Conclusively, the paper makes findings that context-specific and needs-based neo-ijtihād legal rulings of fiqh al-aqalliyyah is still viable in this contemporary period to arrest new jurisprudential challenges facing the Muslim minorities in non-Muslim communities. Also neo-ijtihād exercise of figh al-aqalliyyah from a competent Islamic jurists and legal theorists of a particular society is meant for that society only and should not be given general or universal application so as not to cause confusion in the context-specific and needs-based jurisprudential response. Finally, the study recommends that Muslim minorities should make use of the Islamic jurists and
\end{abstract}

Senior Lecturer, Islamic Legal Studies, Department of Religious Studies, University of Lagos, Lagos, Nigeria. akadegoke@unilag.edu.ng, alfaqasim12@ gmail.com 
legal theorists' neo-Ijtihād exercise of fiqh al-aqaliyyah which are peculiar to their environment in procuring solutions to some of the contemporary Islamic jurisprudential challenges facing them in the non-Muslim community.

Keywords: Fiqh al-Aqalliyyah, neo-ijtihād, Muslim minorities, Contextspecific and Needs-based legal rulings, legal maxims, non-Muslim community

\section{INTRODUCTION}

Ummah as a community of Muslim minorities amidst non-Muslim majorities is being misunderstood as monolithic from religious perspective in the contemporary time whereas in the first ever-existed Muslim community in Madinah under the leadership of Prophet Muhammad and rightly-guided caliphs, Muslim minorities successfully co-existed with non-Muslim majorities. From the time immemorial, several individuals have suffered a lot at the hands of various non-Muslim communities across the globe through the application and imposition of their non-Islamic legal rulings on their personalities. Any refusal attempt from the Muslim minorities against the un-Islamic legal authority always met with stiff opposition and persecution from the concerned non-Muslim communities in the Arabian peninsula. The pages of history are full of maltreatment and persecution faced by the first generation of Muslims at the hand of Arabian pagans in the non-Muslim community of Makkah and its environs. Severe persecutions came upon the less-privileges and slaves among the early Muslims in the Arabian Peninsula. ${ }^{2}$ Contemporary Muslim minorities are not totally free from discrimination and subjugation as a result of various un-Islamic legal authorities of nonMuslim communities imposed on them. Some of these legal authorities of non-Muslims are in contrary with socio-cultural, economic and religious standard of the Muslims. It is not out of tune to point out that Shariah does not go against the idea of Muslim's residing in a non-Muslim community if the occasion or situation demands for it. Such an occasion or situation may either be for business, tourism, expatriated reason, education, health, consulate or ambassadorial reason which will require the Muslim to stay in a secular community which is dominated by non-Muslims. ${ }^{3}$ Islamic jurisprudence does

2 Haykal, M. H, The Life of Muhammad (USA: American Trust Publication, 1935), 90-91. Also see Nadwi, A.A.H, Muhammad Rasulallah (India: Academy of Islamic Research and Publication, 1979), 112.

3 Ali, M. B \& Sudiman, M. S. S. Sudiman, 'Muslims Living in Non-Muslim Lands: Contesting Muhammad Saeed Al-Qahtani's Argument on Hijrah-al-Walā' wal Barā' Nexus,' Journal of Islamic Studies and Culture, vol. 7/2 (2019): 102. 
not become an obstacle that imposes psychological difficulties on Muslims in their co-existence with non-Muslims in the non-Muslim community as a result of the fear that they would not be able to practice their religion as expected. What is germane in this context is that any community chosen by Muslims as a domiciled geographical location calls for the Muslims' attention to make the appropriate adjustments and accommodations of their faith in such a society without infringing on fundamental tenet of his or her religion. Thus, a specific-context and need-based Islamic jurisprudence come in to rescue the Muslim minorities from the embarrassment. As the saying goes 'the necessity brings new invention'. Hence, the need for developing a new form of fiqh, popularly known as 'fiqh al-aqalliyyah' comes up as a result of the increasing needs and demands placed on Muslim minorities residing in the non-Muslim community. ${ }^{4}$ It is on this line that this study aims at examining the fiqh alaqalliyyah, its legal position in Islamic jurisprudence, its legal instruments and its applicability to lessen the physical, social, financial and emotional hardships, difficulties and problems encountered by Muslim minorities who find themselves in an unfamiliar non-Muslim community.

\section{FIQH AL-AQALLIYYAH: WHAT DOES IT MEANS?}

The term 'fiqh al-aqalliyyah' is a combination of two words name; 'fiqh' and 'aqalliyyah'. The word 'aqalliyyah' is derived from Arabic weak verb 'qalla' which linguistically means 'he became small, little, few or less significant in number or quantity'. 5 Thus, aqalliyyah literally means smaller number, numerical inferiority or minority. ${ }^{6}$ Technically, aqalliyyah could be defined as a small group of people who are of different race or faith to most of the people in majority in the same community or country where they reside. ${ }^{7}$ With this understanding, fiqh al-aqalliyyah simply means Islamic jurisprudence of minority. In the context of this study, fiqh al-aqalliyyah is referring to neoIjtihād based Islamic jurisprudence of Muslim minorities residing in a nonMuslim community. Fiqh al-Aqalliyyah is one of the modern developments in Islamic jurisprudence which has been thoroughly discussed through the lens

4 Parray, T.S., 'The Legal Methodology of 'Fiqh al-Aqalliyya' and Its Critics: An Analytical Study,' Journal of Muslim Minority Affairs, vol. 32/1 (1998): 89.

5 Cowan J.M., Hans Wehr Dictionary of Modern Written Arabic (U.S.A.: Spoken Language Service, Inc., 1976), 782.

6 Cowan J.M., Hans Wehr Dictionary of Modern Written Arabic, 783.

7 Oxford Wordpower, Qāmūs Aksfūrd al-Hadīth li al-Darsī Lughah al-Inklīzīyyah (Oxford: Oxford University Press, 1998), 477. 
of context-specific and needs-based neo-ijtihād legal rulings in the light of situational Islamic jurisprudence (fiqh al-waq $\bar{\imath}){ }^{8}$

\section{KINDS OF CONTEMPORARY NON-MUSLIM COMMUNITY}

Non-Muslim community is a geographical and political boundary in which there is great number of non-Muslims in population which their conduct of affairs is derived from the non-Islamic legal principles. The non-Muslim community is divided into two namely; purely-secular non-Muslim community and religiously-inclined non-Muslim community.

\section{Purely-Secular Non-Muslim Community}

The purely-secular non-Muslim community is a community that gives no recognition to any form of religious beliefs. In other word, such a community wholeheartedly adopted a secular life standard and eventually become hostile to religion and any form of belief. As a result of this development, religion is given no role to play in the people's private and public affairs ${ }^{9}$ The people's private and public conduct of affairs is based on secular legal ruling in operation in such community. The best samples of the purely-secular nonMuslim communities are purely-secular non-Muslim communities operating in most of the European countries such as United States of America, Russia, France, Germany et.cetera. ${ }^{10}$

8 The technical term minority fiqh itself was coined by Jabir Taha Al-Alwani in 1994 when the Fiqh Council of North America, under his presidency, issued a fatwa (legal opinion) allowing American Muslims to vote in American elections. For more clarification see; Dudereja, A \& Rane, H., Islam and Muslims in the West; Major Issues and Debates (Switzerland: Palgrave Macmillan, 2019), 212. Also see Fishman, Shammai, 'Fiqh al-Aqalliyyat: A Legal Theory for Muslim Minorities,' Research Monographs on the Muslim World, vol. 1/2 (Washington, DC: Hudson Institute, 2006) and al-Alwani, Taha, Towards a Fiqh for Minorities: Some Basic Reflections (Herndon: International Institute of Islamic Thought, 2003).

9 Adegoke, K.A., 'The Influence of Religion on the Concept of Secularism in Nigeria,' Ilorin Research, the Journal of Postgraduate Students' Association, University of Ilorin, Nigeria, vol. 5/1 (2004): 101.

10 Adegoke, K.A., 'The Influence of Religion on the Concept of Secularism in Nigeria,' 101. 


\section{Religiously-Inclined Non-Muslim Community}

The religiously-inclined non-Muslim community is a community that gives room and recognition to one or many religious beliefs in their geographical domains. In short, such a community is either a uni-religious or multi-religious community which runs the religious practice as private affairs of citizen. ${ }^{11}$ The citizens' public conduct of affairs is not sourced from religious belief because religious matter is viewed as individual private affairs which should not interfere with public affairs of individual citizen in a religiously-inclined nonMuslim community. Their constitutional rights are sourced from secular legal ruling inherited from the borrowed secular values of their imperialist masters. ${ }^{12}$ The best samples of religiously-inclined non-Muslim communities are Catholic Christian community of Vatican City and Rome, Anglican Christian religiously-inclined non-Muslim community in England, Protestant Christian religiously-inclined non-Muslim community in Germany and Ireland, Jewish religiously-inclined non-Muslim community in Israel, Hindu religiouslyinclined non-Muslim community in India, Bhudda religiously-inclined nonMuslim community in some of Asian countries, Confucius religiously-inclined non-Muslim community in China et.cetera. ${ }^{13}$

\section{RE-READING FIQH $A L-A Q A L L I Y Y A H$ AND MUSLIM MINORITIES IN AL-ALWĀNİ'S JURISTIC OPINION}

Al-Alwān̄i, in his reaction to fiqh al-aqalliyyah and Muslim minorities, called for a fiqh renewal (tajdìd al-fiqh) and neo-ijtihād to address the unique experiences of Muslim minorities amidst non-Muslim majorities in a given community. He opines that there are some constitutional rights and protections in some religiously-inclined non-Muslim communities which call for religious freedoms in their constitution which are in favour of Muslim minorities as it gives them the rights to freely practice their faith without the fear of discrimination and intimidation in such communities. Al-Alwānī consequently

11 Oloyede, I. O, "Shari' ah in the North, Concerns of the South: Renewed Controversy Over Shari'ah Law in Nigeria, in Balogun, I. A. B (ed.), Islamic Tenets and the Shari'ah, Nigeria: Sam Bookman Publishers, 146.

12 Adegoke, K.A., 'Dhimmah Contract in Sokoto Caliphate of Nigeria and Contemporary Challenges,' Islamic University Multi-Disciplinary Journal, vol. 7/2 (2020): 154.

13 Bryam, M.D., The Many Faces of Religion and Society (New York: Paragon House Publishers, 1985), 35-37. 
envisages such a non-Muslim community as an Abode of peace (Dār alSalam), Abode of treaty (Dār al-Sulh) and Abode of religious testimony (Dār al-Shahādah) which is quite different from Abode of war (Dār al-Harb) which is hostile to Muslim minorities. ${ }^{14}$ With this understanding, al-Alwānī classifies religiously-inclined non-Muslim community into four namely;

a) The religiously-inclined non-Muslim community which gives recognition to Muslim minorities to freely practice their religion, that is Dār al-Salam (Abode of peace).

b) The religiously-inclined non-Muslim community which enters into peaceful treaty of religious freedom with Muslim minorities, that is Dār al-Sulh (Abode of treaty).

c) The religiously-inclined non-Muslim community which is hostile towards Muslim minorities and their religious belief, that is Dār al-Harb (Abode of war).

d) The religiously-inclined non-Muslim community which transforms itself to Islamic state by its adoption of Islam as a religion and Shariah as its constitution, that is Dār al-Shahādah or Dār al-Islam.

Al-Alwānī contests the legal proposition of some scholars which gives credence to the geographical and territorial distinctions of the Muslim and non-Muslims residing in a single geographical boundary, after all, there is no textual evidence on this proposition in the Quran and Sunnah of the Prophet (SAW). He justifies fiqh al- 'aqalliyyah with the traditional and contemporary methodology of Islamic jurisprudence at one hand and viability of higher objectives of Shariah popularly called maqāșid al-sharī'ah at other hand with universality of Islam as a global and inclusive faith. Consequently, alAlwānī proposes integration of Muslim minorities with their host non-Muslim communities. To successfully do this, there is need for a competent jurist and legal theorist who can appropriately balance the equation between contextspecific values and needs-based rulings for Muslim minorities living in the nonMuslim community where they are faced with new situational challenges that go beyond their basic and traditional socio-religious practices like taking halāl food, drinking and marrying non-Muslim women, and modern medical means such as family planning, surrogacy, human cloning, organ transplantation, abortion, test-tube baby, prosthetic surgery, milk banking, genetic counselling and marrying non-Muslim women. ${ }^{15}$

\footnotetext{
14 Al-Alwani, Taha, Towards a Figh for Minorities: Some Basic Reflections.

15 Al-Alwani, Taha, Towards a Fiqh for Minorities: Some Basic Reflections, xxii. See also Adegoke, K.A., 'The Practice of Ta'addud al-Zawjah under Sharī'ah and Neo-Ijtihād Challenges among the Contemporary Muslims,' Ilorin Journal of Religious Studies, vol. 1/2 (2011): 47.
} 


\section{RE-READING FIQH $A L-A Q A L L I Y Y A H$ AND MUSLIM MINORITIES IN AL-QARADĀWĪ'S JURISTIC OPINION}

Al-Qaraḍāwī classified religiously-inclined non-Muslim communities into three namely; ${ }^{16}$

a) The religiously-inclined non-Muslim community governed by Muslims despite the fact that they are in minorities, that is Dār al-Islam. (Abode of Islam). The best sample of this is the first-ever Ummah Muslim community in Madinah which was founded by Prophet Muhammad.

b) The religiously-inclined non-Muslim community which has entered into diplomatic or peaceful ties with Muslim minorities or the non-Muslim community which is friendly towards Muslim minorities and their religious belief under their domains, that is Dār al-Sulh (Abode of treaty).

c) The religiously-inclined non-Muslim communities which are at war or hostility with the Muslim minorities, that is Dār al-Harb (Abode of war).

The theological rationale behind the fiqh al-aqalliyyah of al-Qaraḍāwī is grounded in the universalism and pan-Islamism of Islam in the Muslim and non-Muslim communities which also calls for competent jurists and legal theorists who can appropriately balance the equation between context-specific values with needs-based rulings for Muslim minorities in the concerned nonMuslim community amidst new jurisprudential challenges facing them which go beyond their basic and traditional religious practices. According to him, in the religiously-inclined non-Muslim communities which has entered into diplomatic or peaceful ties with Muslim minorities, Muslim minorities should see themselves as an integral and inseparable part of the whole Muslim world as well as being part of its indigenous peaceful non-Muslim communities of their domicility. Unlike al-Alwān̄i, al-Qaraḍāwī does not totally subscribe to the integration philosophy of al-Alwānī, instead, he lays more emphasis on the importance of having an Islamic presence in the non-Muslim communities for the purpose of proselytisation and evangelization of Islam ( $\mathrm{da}$ ' wah). ${ }^{17}$

\footnotetext{
16 Al-Qaradawi, Y, Fiqh of Muslim Minorities (Cairo: Al-Falah Foundation, 2003), 6.

17 Whyte, S., 'Whither Minority Jurisprudence? The Case of Fiqh Al-Aqalliyat in Australia,' Australian Journal of Islamic Studies, vol. 2/3 (2017): 57.
} 


\section{FIQH AL-AQALLIYYAH AND MUSLIM MINORITIES IN SECULAR NON-MUSLIM COMMUNITIES}

The Islamic jurists and legal theorists are divided into two factions on the jurisprudential capacity of fiqh al-aqalliyyah in non-Muslim community. Some Islamic jurists and legal theorists like Jabir Taha al-Alwānī and Yūsuf al-Qaraḍ̄wī give assent to viability and applicability of fiqh al-aqalliyyah in the contemporary period while other Islamic jurists and legal theorists like Hamud Ibn Uqla al-Shu'aybī and 'Abd al-'Azīz Ibn 'Abd Allāh al-Shaykh among twentieth century Salafis and Wahhabis do not as a result of their doctrine of al-Wala ' wa al-Bara ${ }^{\prime}{ }^{18}$ Those Islamic jurists and legal theorists, who subscribe to fiqh al-aqalliyyah, opine that fiqh al-aqalliyyah is a kind of jurisprudential exercise which is circumstantial, situational and geographically bounded so as to meet the challenges of the time facing the Muslim minorities in non-Muslim communities in the contemporary period. ${ }^{19}$

Fiqh al-Aqalliyyah is well structured and designed by some seasoning contemporary Islamic jurists and legal theorists so as to secure the affairs and rights of Muslims minorities residing in non-Muslim communities where the religion is not given full recognition or where religion does not have a say in their private and public affairs. ${ }^{20}$ It is not out of tune to specifically mention at this juncture that the brains behind this theory of fiqh al-aqalliyyah is no one rather than the two modern seasoning legal theorists and classically-trained Muslim jurists, Tahā Jābir al-Alwānī (d. 2016) and Yūsuf al-Qaraḍāwī, who invented it as a juristic strategy to address the needs of Muslim minorities in the midst of non-Muslim majorities in a particular community. Both scholars elucidated materials from Islamic foundational sources, the Quran and Sunnah, together with well-established legal maxims (qawā'id al-fiqhiyyah) to legitimize the necessity of context-specific and needs-based legal rulings for Muslim minorities living in the non-Muslim majority communities. ${ }^{21}$

18 Ali, M.B., 'al-Walā' wa al-Barā' in Wahhabism: From A Tool to Fight Shirk to Takfir of Muslim Leaders,' Journal of Islamic Studies and Culture, vol. 7/1 (2019): 37.

19 Adegoke, K.A., 'Neo-Ijtihād in the Modern Legal Studies: A Case Study of alQaraḍāwī's Concept of Neo-Ijtihād,' International Journal of Fiqh and Usul alFiqh, vol. 4/1 (2020): 115.

20 Al-Qaraḍāwī, Y., al-Fiqh al-Islāmī bayna Aṣālah wa al-Tajdīd (Qāhirah: Maktabah al-Wahbah, 1997), 1-ff.

21 Whyte, S., 'Whither Minority Jurisprudence? The Case of Fiqh Al-Aqalliyat in Australia,' 57. 
Both Tahā Jābir al-Alwānī and Yūsuf al-Qaraḍāwī wrote several materials on the fiqh al-aqalliyyah. The former wrote 'Towards a Fiqh for Minorities: Some Basic Reflections' while the latter wrote 'Fiqh of Muslim Minorities'. These fiqh materials are highly and essentially need in the contemporary time when there is, on daily basis, a lot of migrations of the Muslim minorities into the non-Muslim metropolitan communities in search of greener pasture or in pursuance of advancement in scientific and technological education. This development prompted some modern day Islamic jurists (fuqahä' almu'așșirìn) and islamic legal theorists (ușüliyyūn al-mu'așsirīn) to employ renewal of Islamic jurisprudence (tajdìd al-fiqh) so as to deduce Islamic legal theory within the context-specific and situational-need based legal ruling for the modern day Muslim minorities. ${ }^{22}$ It is not out of tune to say at this juncture that there are some modern day Islamic jurists and legal theorists who do not subscribe to fiqh al-aqalliyyah. ${ }^{23}$

Some of these anti-fiqh al-aqalliyyah scholars are Muhammad Khalid Mas'ud, Tariq Ramadan and Mohamed Mestri. Each of them wrote materials on fiqh al-aqalliyyah such as Islamic Law and Muslim Minorities, Western Muslims and the Future of Islam and from the Figh of Minorities to the Fiqh of Citizenship respectively. The jurisprudential argument of these Islamic jurists and legal theorists is based on the consequential problem which would rise up as a result of application of fiqh al-aqalliyyah in the contemporary period such as question of the conceptual understanding of fiqh al-aqalliyyah, universal applicability of fiqh al-aqalliyyah and status of Muslim minorities in non-Western contexts and at sub-national level as a result of the division of Muslims into different linguistic and ethnic groups. ${ }^{24}$

\section{LEGAL INSTRUMENTS OF FIQH AL-AQALLIYYAH}

Fiqh al-aqalliyyah, in its practical application, is powered through the legal exercising of some subsidiary sources of Islamic jurisprudence like mașlahah, istiḥsān, istiṣlāh and maṣāliḥ al-murșalah, legal maxims (qawā'id alfiqhiyyah), rukhșah and takhāyyur modern legal theory on the necessity (aldarürah) which seek to permit individual Muslim minorities to derive their

22 Ali, M. B \& Sudiman, M. S. S. Sudiman, 'Muslims Living in Non-Muslim Lands: Contesting Muhammad Saeed Al-Qahtani's Argument on Hijrah-al-Walā' wal Barā' Nexus,' 102.

23 Whyte, S., 'Whither Minority Jurisprudence? The Case of Fiqh Al-Aqalliyat in Australia,' 58-59.

24 Whyte, S., 'Whither Minority Jurisprudence? The Case of Fiqh Al-Aqalliyat in Australia,' 60. 
own legal rulings in times of hardship and necessity in order to lessen the physical, social, financial and emotional hardships or difficulties facing by Muslim minorities living in an unfamiliar non-Muslim community. It should be rightly mentioned at this juncture that the application of fiqh al-aqalliyyah for Muslim minorities residing in a non-Muslim community is in line with the textual facts from the Quran and Sunnah which go thus;

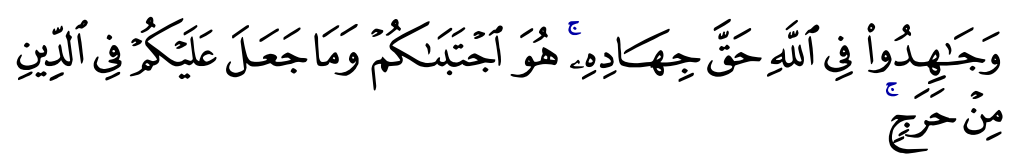

"And strive for God as He should be striven for. He has chosen [for] you - and has placed no hardship for you in the religion."

(Surah al-Hajj, 22: 78)

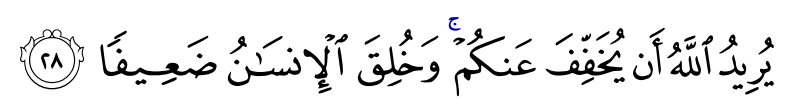

"Allah wishes to lighten your (difficulties) because man was created weak."

(Surah al-Nisā', 4: 28)

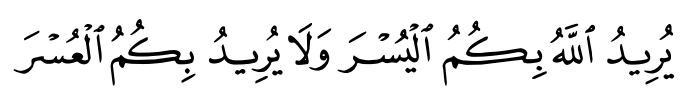

"Allah intends for you ease, and He does not want to make things difficult for you."

(Surah al-Baqarah, 2: 185)

Prophet Muhammad (SAW) was reported to have said;

$$
\text { يسرواو لاتعسوا وبشرواو لانفروا }
$$

"Facilitate things for people (concerning religious matter), and do not make it hard for them and give them good tidings and do not make them run away (from Islam). " 25

It was also reported by ' $\bar{A}$ 'ishah that she said;

$$
\text { ما خير رسول الله بين امرين فى الاسلام الا اختار ايسر هما }
$$

25 Al-Bukhārī, M. I. I, Șah̄ịh al-Bukhārī, Arabic-English (Chapter of Knowledge Hadith 63), (Lubnān: Dār al-Fikr, 1401), 63. 


\begin{abstract}
"Whenever two matters were offered to the Prophet (SAW) to choose between them, the Prophet would always choose the easiest one unless it was harām." 26
\end{abstract}

Islamic jurists and legal theorists make use of any of the above-mentioned legal sources of Islamic jurisprudence to exempt Muslims from conducting basic and traditional religious practices that would not contradict purelysecular or religiously-inclined non-Muslim community laws or deprive them of the opportunity to actively participate in the lawful activities in Islam such as slaughtering a cow for food in the Hindu community where the cow is taken as sacred and spiritual animal representing their gods. ${ }^{27}$ These legal sources are discussed below;

\title{
1. Maṣlahah between Fiqh al-Aqaliyyah and Muslim Minorites
}

Mașlaḥah literally means benefit, interest or utility. Technically, it means an unrestricted public interest accorded to Muslim minorities in a secular non-Muslim community in the sense of its not have been regulated by Allah SWT in so far as no legal ruling can be found on its validity or otherwise. ${ }^{28}$ This consists of considerations which secure a benefit or prevent a harm for Muslim minorities but which are, simultaneously, harmonious with the objectives of Shariah (maqāssid al-sharī'ah) such as religion, life, property, lineage, intellectual and dignity. ${ }^{29}$ Thus, any action which can tamper with this objectives of Shariah (maqāșid al-sharī'ah) or which can lead to difficulty (darar) and corruption (mafsadah) in the life of Muslim minorities in a secular non-Muslim community has to be prevented by fiqh al-aqaliyyah through maṣlaḥah. This mașlaḥah can be showcased in fiqh al-aqaliyyah through some of the subsidiary legal sources of Islamic jurisprudence such as istihsān, istiṣlāh and mașalih al-murṣalah which are going to be briefly highlighted; ${ }^{30}$

26 Hanbāl, Aḥmad Ibn, Musnad al-Imām Ahmad Ibn Hanbāl, vol. 6, no. 24593 (Qāhirah: Qurtubah Foundation Press, 1418).

27 Ihsan Yilmaz, 'Micro-Mujtahids and Implementation of Fiqh al-Aqalliyat,' in Rethinking Islamic Law for Minorities: Towards a Western-Muslim Identity, ed. Jasser Auda (London: Association for Muslim Social Scientists, 2016).

28 Kamali, M.H., Principles of Islamic Jurisprudence (UK: The Islamic Texts Society, 1991), 267.

29 Alnemari, H.H., 'Utilitarianism in Classic Islamic Jurisprudence,' Journal of Islamic Studies, vol. 5/1 (2017): 1.

30 Kamali, M.H., Principle of Islamic Jurisprudence, 276-277. 
Istiṣlăh: Istiṣlāh is derived from Arabic verb 'istașlaha' which means to seek for amendment or correction. It literally means an amendment or correction. Technically, it means a method of seeking facility and easiness for Muslim minorities in a secular non-Muslim community public welfare in legal injunction.

Istihssān: Istih̆sān is derived from Arabic verb 'istahsana' which means to seek for preferable option. It literally means juristic preference or public interest. Technically, it is a method of exercising personal opinion in order to avoid any rigidity and unfairness for Muslim minorities in a secular non-Muslim community that might result from the literal enforcement of the existing law in public.

Mașlahah Mursalah: Mașlahah Mursalah means a rule applicable to Muslim minorities in a secular non-Muslim community which has no specific basis in the established law (Quran and Sunnah), whether in favour or against.

\section{Qawā'id al-Fiqhiyyah between Fiqh al-Aqaliyyah and Muslim Minorities}

Qawā'id al-fiqhiyyah literally means legal maxims. Technically, it refers to a body of abstract rules which are derived from the detailed study of the Islamic jurisprudence. ${ }^{31}$ In the context of this study, it could be defined as an all-inclusive rule based on legal evidence written accurately in comprehensive words in order to lessen the societal difficulties and hardship of Muslim minorities residing in a non-Muslim community. It is derived from the Quran, Sunnah, Athār of Prophet's companions (sahābah) and their disciples (tabi ' 'unn). The purpose of qawa' 'id al-fiqhiyyah is to simplify and to assemble the branches of Islamic jurisprudence ( $($ ur $\bar{u})$ and to prove that Islamic jurisprudence leaves no matter untouched irrespective of place, time, condition, situation and circumstance. In fact, qawa' 'id al-fiqhiyyah would serve as a legal mechanism that would enable Islamic jurists and legal theorists to react to any jurisprudential matter related to new and recent events. ${ }^{32}$ The followings are some of the qawa' id al-fiqhiyyah ${ }^{33}$ which are explored to bring out fiqh al-aqaliyyah in order to

\footnotetext{
31 Kamali, M.H., Principle of Islamic Jurisprudence, 5.

32 Ahmad, M.M., al-Qawā id, vol. 1 (Saudi Arabia: Islamic Researches Institute, Umm al-Qura University, n.d.), 114.

33 Mishkat, al-Qawā'id al-Fiqhiyyah (Legal Maxims of Islamic Jurisprudence), A Translated Compilation (USA: Islamic University of North America (Mishkah), Islamic Studies English Program, 2013), 92-100.
} 
safeguard the public welfare and interest of Muslim minorities residing in a non-Muslim community;

a) al-Mashaqqah Tajlīb al-Taysīr (Hardship begets Ease)

b) Idhā Dhā al- 'Amr ittasha 'a Dhāq ittasha 'a (When a matter tightens, it will widen and vice-versa)

c) al-Ḍarūrāt Tubī'h al-Maḥz̄ūrāt (Necessity renders prohibited matters permissible)

d) al-Darūrah Biqadarihā (Necessities are with their limit)

e) Ma Ubīha li Darūrah Yuqaddar bi Qadarihāa (Necessities have limits that should not be exceeded)

f) Mā Jāza li 'Udhri Bațala bi Zawālih (What becomes legal by a valid excuse, will become illegal when the excuse ends)

g) al-Hājah Tanzīl Manzilah al-Darūrah 'Ammah Aw Khāṣșah (General or particular need can develop into necessity)

h) Idhā Ta 'adhar al- 'Aṣl Yuṣār ilā al-Badal (When the fundamental something is not available, we proceed to alternative)

Fiqh al-Aqalliyyah permits that necessitated situation, circumstance and occasion have to be given consideration in the jurisprudential matter as a legal base for the permission of Muslim to engage in what has been originally unlawful under normal situation, circumstance and occasion. ${ }^{34}$ There are several proofs from the Quran and prophetic traditions of the Prophet (SAW) in support of qawā 'id al-fiqhiyyah on this regard such as Quran 16: 106 which reads thus;

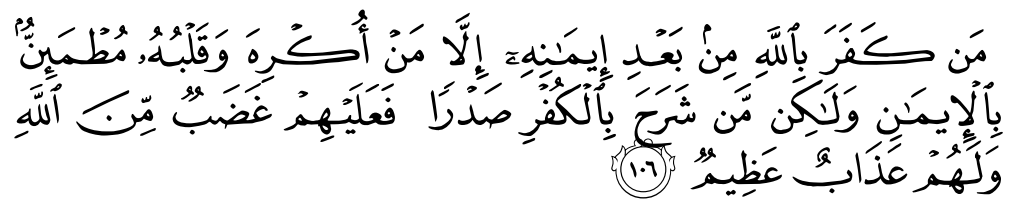

"He who disbelieves in Allah after his belief (Imān), except he who is compelled while his heart is at rest on account of faith, but he who opens his breast to disbelief, on these is the wrath of Allah, and they shall have a grievous chastisement."

(Surah al-Nahl, 16: 106)

34 Elesin, A.M.J., 'Legitimisation of Boko Type of Education within the Framework of the Shari 'ah Principle al-Darūrāt Tubịh al-Maḩzūūāt in Yusuf, B.O,' Journal of the Nigeria Association of Teachers of Arabic and Islamic Studies, vol. 15 (2012): 51. 


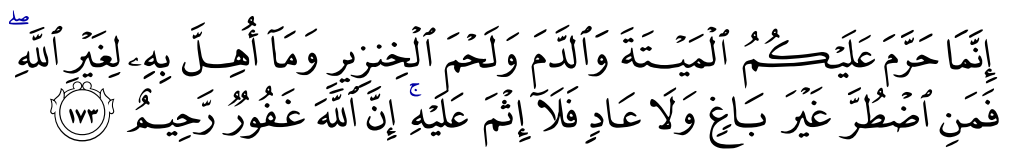

"He (Allah) has only forbidden you what dies of itself, and blood, and the flesh of swine, and that over which any other name than that of Allah has been invoked, but whoever is driven to necessity, not desiring, nor exceeding the limit, no sin shall be upon him. Surely, Allah is oft-Forgiving, Most Merciful."

(Surah al-Baqarah, 2: 173)

\section{RUKHSTAH BETWEEN FIQH AL-AQALIYYAH AND MUSLIM MINORITIES}

Rukhṣah may not be properly understood without proper conception of 'ażimah. 'Azimah literally means strict legal ruling. Technically, it is a strict legal ruling when such a legal ruling is in its primary and unabated legal force without reference to any attenuating circumstances which may soften its original force or even entirely suspend it. In fact, 'ażimah is a strict legal ruling (qaț' $\grave{\imath})$ as Allah SWT, the Law Giver had intended in the primary source of Shariah (Quran and Sunnah) such as obligations of șalāh, zakāh, șawm, hajj, jihād et.cetera, which the Law Giver has enjoined upon all competent individual Muslims (mukallaf). ${ }^{35}$ Rukhșah literally means concession. Technically, rukhșah is a concessional law by contrast, when it is considered in conjunction with circumstances, conditions and situation. In other word, 'azimah is the law in its normal state, while the rukhsah embodies the concessions and exceptions. In the context of this study, rukhșah is a concessional and exceptional legal ruling by contrast, for Muslim minorities in a purely-secular or religiously-inclined non-Muslim community in the contemporary time, when such a legal ruling is considered in conjunction with circumstances, conditions and situation with the aim of bringing facility and easiness to the beneficiaries (Muslim minorities).

For instance, $a l$-wudu', the water ablution is the normal command ( 'azimah) from Allah, the Law Giver when preparing for șalah but tayammum, the dry ablution is the exception and concession (rukhșah) when the water is neither available nor accessible. ${ }^{36}$

35 Khallaf, A., 'Ilm Ușūl al-Fiqh (Kuwait: Dār al-Qalam, 1398AH), 120.

36 Abū Zahrah, M., Ușūl al-Fiqh (Qāhirah: Dār al-Fikr al-'Arabī, 1986), 50. 
Kamali is right to have pointed out that rukhșah is applicable in any of the following four abnormal or difficult circumstances; ${ }^{37}$

a) Permitting a prohibited act on grounds of necessity, such as eating the flesh of a carrion or drinking a wine at the point of drought or starvation and extreme famine.

b) Rukhșah may occur in the omission of an obligatory act (wajjib) when conformity with that obligatory act would cause hardship. For instance, shortening of prayer during travel (qașr).

c) Rukhșah may occur in the area of commercial transactions in the form of validating commercial contracts which would be disallowed in a normal situation. For instance, lease and hire (ijärah), advance sale (bay' al-salam) and the order for manufactured goods (istișnā) which are not existent at the time of contract, but they are permitted exceptionally in order to accommodate the public need for such transactions.

d) Rukhșah may occur in the form of concessions to the Muslim community from certain rigorous legal ruling which were imposed under previous revelation or secularism.

\section{TAKHĀYYUR BETWEEN FIQH AL-AQALIYYAH AND MUSLIM MINORITIES}

Takhāyyur literally means a modern legal option. Technically, it is a variety of legal rules which leaves individual at liberty to choose the best legal option out of several legal options from different schools of legal thought. ${ }^{38}$ Contextually, it is a variety of legal rules which leaves individual at liberty to choose context-specific and needs-based legal rulings for Muslim minorities living in the non-Muslim majority community out of several legal options from different Islamic jurists and legal theorists. In the process of exercising fiqh al-aqalliyyah in favour of Muslim minority residing in a purely-secular or religiously-inclined non-Muslim community in the contemporary time, there is an ample opportunity of making use of takhayyur or legal option through inter and intra madhhab legal surfing so as to navigate for appropriate legal rulings in times of necessity and new circumstance. Individual Muslim in a purely-secular or religiously-inclined non-Muslim community has the right to choose an appropriate madhhab or legal ruling in times of necessity, hardship

37 Kamali, M.H., Principle of Islamic Jurisprudence, 340.

38 Kamali, M.H., Principle of Islamic Jurisprudence, 321. 
and difficulty which will enable them to make swift decisions to resolve minor jurisprudential issues. There are also several proofs from the Quran and prophetic traditions of the Prophet (SAW) which are in support of takhāyyur legal option. For instance;

Allah SWT says in Quran;

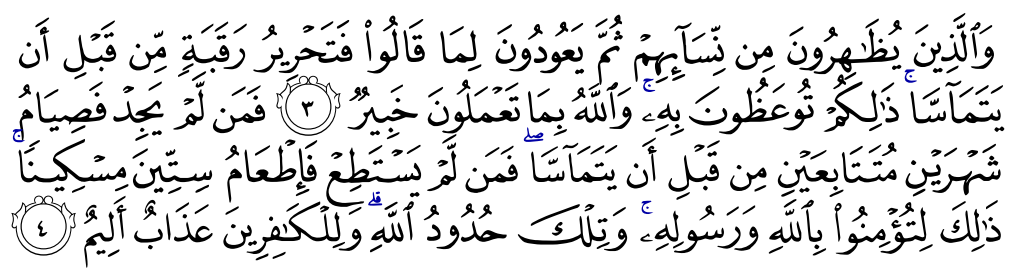

"And for those who put away their wives by likening their backs to the backs of their mothers (zihār), then would recall what they said, they should free a captive before they touch each other, to that you are admonished to conform, and Allah is aware of what you do. But whoever has not the means, let him fast for two months successively before they touch each other, then as for him who is not able, let him feed sixty needy ones, that is in order that you may have faith in Allah and His Messenger, and these are Allah's limits, and the unbelievers shall have a painful punishment."

(Surah Mujādalah, 58: 3-4)

Prophet (SAW) was reported to have said that;

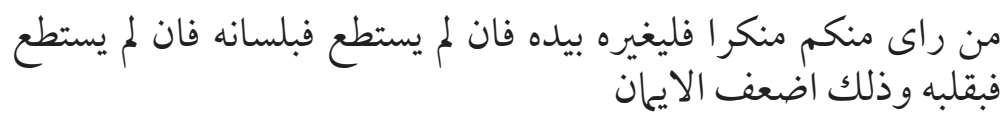

"When anyone of you sees anything that is disapproved, let him change it with his hand; if that is not possible, then with his tongue; and that if that is not possible, then with his heart, though this is the weakest form of faith." 39

The results of the study and suggestions obtainable from these aforementioned legal instruments of fiqh al-aqalliyyah showcase that fiqh alaqalliyyah could be extended and employed in the modern daily life in nonMuslim community in the acts of obtaining interest-based home loans, adjusting fasting and prayer times, marrying non-Muslim, political participation and

39 Al-Nawawī, M.A.Y.S., Matn al- 'Arba 'ìn al-Nawawiyyah fì al-Ahāāìth al-Ṣaḥīhah al-Nabawiyyah (Lajūs, Nijriyyah: Multazim al-Ṭaba' wa al-Nashr, n.d.), no. hadìth 34, 40-41. 
military service within the context-specific and needs-based jurisprudential excuses.

\section{CONCLUSION}

In this study, we are able to consider and establish the fiqh aqalliyyah as one of modern jurisprudential approaches to the methodological utilization of neo-ijtiha $\bar{a} d$ to cater for the welfare of Muslim minorities in a non-Muslim community in the contemporary period when the general rule, if applied, would bring hardship and difficulty on them or would make Islamic law inapplicable.

This study observes that;

a) context-specific and needs-based legal rulings of fiqh aqalliyyah is still viable in this contemporary period to arrest new jurisprudential challenges facing the Muslim minorities in the non-Muslim communities.

b) Neo-ijtihād exercise of fiqh aqalliyyah of a competent Islamic jurists and legal theorists of a particular society is meant for that society only and should not be given general or universal application so as not to misconceive the context-specific and needs-based jurisprudential response.

The study therefore, recommends that Muslim minorities should make use of the Islamic jurists and legal theorists' neo-ijtihād exercise of fiqh aqalliyyah which are peculiar to their environment in procuring solutions to some contemporary Islamic jurisprudential challenges facing them in non-Muslim community.

\section{REFERENCES}

Abū Zahrah, M., Ușūl al-Fiqh (Qāhirah: Dār al-Fikr al-‘Arabī, 1986).

Adegoke, K.A., 'The Practice of Ta 'addud al-Zawjah under Shari' 'ah and NeoIjtihād Challenges among the Contemporary Muslims,' Ilorin Journal of Religious Studies, vol. 1/2 (2011): 37-50.

Adegoke, K.A., 'Neo-Ijtihād in the Modern Legal Studies: A Case Study of alQaraḍāwī's Concept of Neo-Ijtihād,' International Journal of Fiqh and Usul al-Fiqh, vol. 4/1 (2020): 108-117.

Adegoke, K.A., 'Dhimmah Contract in Sokoto Caliphate of Nigeria and Contemporary Challenges,' Islamic University Multi-Disciplinary Journal, vol. 7/2 (2020): 150-158. 
Adegoke, K.A., 'The Influence of Religion on the Concept of Secularism in Nigeria,' Ilorin Research, the Journal of Postgraduate Students' Association, University of Ilorin, Nigeria, vol. 5/1 (2004): 99-109.

Ahmad, M.M., al-Qawā id, vol. 1 (Saudi Arabia: Islamic Researches Institute, Umm al-Qura University, n.d.).

Al-Alwani, Taha, Towards a Fiqh for Minorities: Some Basic Reflections (Herndon: International Institute of Islamic Thought, 2003).

Al-Bukhārī, M. I. I, Șah̄ịh al-Bukhārī, Arabic-English, (Chapter of Knowledge Hadith 63) (Lubnān: Dār al-Fikr, 1401).

Ali, M.B. \& Sudiman, M.S.S. Sudiman, 'Muslims Living in Non-Muslim Lands: Contesting Muhammad Saeed Al-Qahtani's Argument on Hijrahal-Walā' wal Barā' Nexus,' Journal of Islamic Studies and Culture, vol. 7/2 (2019): 97-106.

Ali, M.B., 'al-Walā' wa al-Barā' in Wahhabism: From A Tool to Fight Shirk to Takfir of Muslim Leaders,' Journal of Islamic Studies and Culture, vol. 7/1 (2019): 28-43.

Al-Nawawī, M.A.Y.S., Matn al-'Arba'inn al-Nawawiyyah fì al-Ahādīth alȘahīhah al-Nabawiyyah (Lajūs, Nijriyyah: Multazim al-Ṭaba‘ wa alNashr, n.d.).

Alnemari, H.H., 'Utilitarianism in Classic Islamic Jurisprudence,' Journal of Islamic Studies, vol. 5/1 (2017): 1-8.

Al-Naysabūrī, M. H. M, Șaḥịh Muslim (Lubnān: Dār al-Fikr, 1410).

Al-Qaraḍāwī, Y., al-Fiqh al-Islāmī bayna Aṣālah wa al-Tajdīd (Qāhirah: Maktabah al-Wahbah, 1997).

Al-Qaradawi, Y., Fiqh of Muslim Minorities (Cairo: Al-Falah Foundation, 2003).

Bryam, M.D., The Many Faces of Religion and Society (New York: Paragon House Publishers, 1985).

Cowan J.M., Hans Wehr Dictionary of Modern Written Arabic (U.S.A.: Spoken Language Service, Inc., 1976).

Dudereja, A \& Rane, H., Islam and Muslims in the West; Major Issues and Debates (Switzerland: Palgrave Macmillan, 2019).

Elesin, A.M.J., 'Legitimisation of Boko Type of Education within the Framework of the Shari 'ah Principle al-Darūrāt Tubīh al-Maḥz̄ūāt in Yusuf, B.O,' Journal of the Nigeria Association of Teachers of Arabic and Islamic Studies, vol. 15 (2012): 48-56. 
Fishman, Shammai, 'Fiqh al-Aqalliyyat: A Legal Theory for Muslim Minorities,' Research Monographs on the Muslim World, vol. 1/2 (Washington, DC: Hudson Institute, 2006).

Hanbāl, Aḥmad Ibn, Musnad al-Imām Ahmad Ibn Hanbāl, vol. 6, no. 24593 (Qāhirah: Qurtubah Foundation Press, 1418).

Haykal, M. H, The Life of Muhammad (USA: American Trust Publication, 1935).

Ihsan Yilmaz, 'Micro-Mujtahids and Implementation of Fiqh al-Aqalliyat,' in Rethinking Islamic Law for Minorities: Towards a Western-Muslim Identity, ed. Jasser Auda (London: Association for Muslim Social Scientists, 2016).

Kamali, M.H., Principles of Islamic Jurisprudence (UK: The Islamic Texts Society, 1991).

Khallaf, A., 'Ilm Ușūl al-Fiqh (Kuwait: Dār al-Qalam, 1398AH).

Mishkat, al-Qawā id al-Fiqhiyyah (Legal Maxims of Islamic Jurisprudence), A Translated Compilation (USA: Islamic University of North America (Mishkah), Islamic Studies English Program, 2013).

Nadwi, A.A.H, Muhammad Rasulallah (India: Academy of Islamic Research and Publication, 1979).

Oxford Wordpower, Qāmūs Aksfürd al-Hadīth li al-Darsī Lughah alInklīzìyyah (Oxford: Oxford University Press, 1998).

Parray, T.S., 'The Legal Methodology of 'Fiqh al-Aqalliyya' and Its Critics: An Analytical Study,' Journal of Muslim Minority Affairs, vol. 32/1 (1998): 88-107.

Whyte, S., 'Whither Minority Jurisprudence? The Case of Fiqh Al-Aqalliyat in Australia,' Australian Journal of Islamic Studies, vol. 2/3 (2017): 55-75. 
Jurnal Syariah, Jil. 29, Bil. 1 (2021) 1-20 